\title{
THE "SON" AS ORGAN OF REVELATION
}

\section{BENJAMIN W. BACON}

Among the most notable contributions of recent years by classical philologians to New Testament interpretation is E. Norden's Agnostos Theos (Berlin, 1913), a comparison of the Lukan account of Paul's missionary career and preaching with Hellenistic parallels, more particularly the biography by Philostratus of Apollonius of Tyana. As a further example of the same method of literary parallels Norden appends a discussion in the last chapter of this book (Schlussbetrachtung, pp. 277308) of the famous logion, or saying of Jesus, from the Second Source $(\mathbf{Q})$ on the Son's Knowing the Father and being Known of Him (Mt. 11 25-30=Lk. 10 21-22).

Parallels from Hellenistic literature put the 'Johannine passage' in a new light. We recognize it in any event as a fragment; for the antecedent of raṽra ("these things") is wanting both in Matthew and Luke. But Norden proves it lyric poetry. Its opening clause "I thank thee,

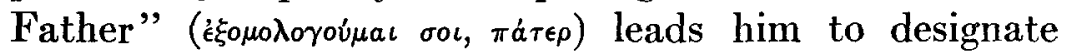
it a hymn of thanksgiving for divine revelation. He divides it according to literary type into three strophes, each consisting of four corresponding lines:

I. $a$ I thank thee, Father, Lord of heaven and earth

$b$ Because thou didst hide these things from the wise and understanding

$c$ And didst reveal them unto babes

$d$ Yea, Father, for such was the Good-pleasure in thy sight.

II. $a$ All things were revealed to me by my Father

$b$ And none hath known the Son save the Father

$c$ Neither hath any known the Father save the Son

$d$ And he to whomsoever the Son willeth to reveal Him. 
III. $a$ Come unto me all ye that labor and are heavy laden

$b$ Take my yoke upon you and learn of me

$c$ And ye shall find rest for your souls

$d$ For my yoke is easy, and my burden is light.

Subject, contents, and rhythmic structure confirm Norden's judgment based on the opening words of the lyric, and the judgment receives further corroboration from the formula by which our third evangelist intro-

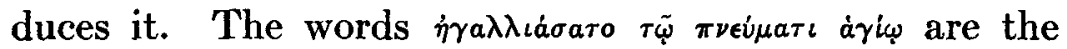
substantial equivalent of those previously employed for lyric citations in Lk. $141-44$ and 67 , and might fairly be rendered "He broke into inspired song."

If the 'Johannine logion' is really a quoted hymn of thanksgiving for divine revelation belonging to a specific type of rejigious lyric, interpreters who thus far have been content merely to point out its general dependence in thought and hraseology on Ecclus. 50-51, will need to revise their judgments. At least the present writer, whose article entitled "Jesus the Son of God" in the Harvard Theological Review for July, 1909 (II, 3) ${ }^{1}$ endeavored to interpret the logion "in harmony with the rest of Synoptic tradition," feels now a double obligation; first, to express deep indebtedness, second, to point out if possible how profoundly all questions of Christology are affected by the evidence connecting this most fundamental of all Christological passages with a whole series of kindred poems.

The Synoptic context of the logion (Mt. 11 20-24= Lk. $1013 \mathrm{f}$.) is an upbraiding of the unrepentant cities of Galilee. As pointed out in our former article, the evangelists seem to take the "wise and understanding" as meaning the Jewish scribes, boastful of their knowledge of God (Rom. 2 17-20). Wisdom's children, the "babes," are the repentant "little ones" of Galilee. The hidden mystery revealed to them is the true tradition of right religion, "all things" being used in the

${ }^{1}$ Subsequently republished under the same title in a volume of essays in Christology by the Yale University Press (1911). 
sense "all truth." Since this right knowledge is accessible only to him who has the filial attitude and spirit, Jesus as the son (generic) can alone truly reveal the Father.

This interpretation fulfils at least the important requirement of relating a passage so unique in Synoptic literature as to have earned the designation "the Johannine passage" ${ }^{2}$ to its Synoptic context. It at least looks toward the truth, and will be seen to coincide in important respects with Norden's. But the new developments reveal its inadequacy. The vital questions remain: What was the original application and meaning of the hymn? Is its 'Johannine' character and style to be explained by the currency of 'Johannine' logia of Jesus; or is it an erratic block, like the quotation from "the Wisdom of God" in Lk. 11 49-51; 13 34 f.=Mt. 23 34-39, representing a mode of thought and speech antecedent to the Johannine? In that case it is not the fourth Gospel which should be used to interpret the logion, but the logion and its connections which should be used to interpret the fourth Gospel. For the theme of the Johannine writer is no other than this same saving gnosis which comes to the world through the Son's revelation of the Father.

Apropos of literary affinities it will be remembered that the logion was shown to have connection with the agraphon "My mystery belongs to me and to the sons of my household"3 as well as with Mk. 4 11, "To you is given the mystery," \&c. It was further brought into parallelism with a number of Pauline passages including 1 Cor. 1 18-3 2, where we hear of the wisdom hidden by God in a mystery from the wise of the world but revealed through the Spirit of Christ.

${ }^{2}$ So e.g. in Schmiedel's article "Die Johanneische Stelle bei Matthüus und Lukas" in Prot. Monatshefte, IV (1900), $15 \mathrm{ff}$.

${ }^{3}$ Clem. Al. Strom. v, 10, 69. In Clem. Hom. xix, 20 it appears in the form "Keep the mysteries for me and the children of my household"; cf. Odes of Sol. viii. 11.

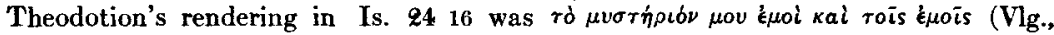
secretum meum mihi). This probably represents a pre-Christian targumic tradition the common source of all these variants. 
What now remains to be shown (and can be shown with the aid of Norden's contribution) is that the fundamental connection of the logion with 'Johannine' conceptions is indirect. The common roots of both are in that mystical literature which we may designate Lyric Wisdom, whereof classic examples are to be found in the 'Songs' of Prov. 1 7-9 18, Ecclus. 24, Wisdom of Solomon entire, and Bar. $39-5$ 9. The material has recently been vastly enriched by the discovery of the so-called Odes of Solomon.

The fourth evangelist cannot, of course, have failed to know the logion as quoted by Matthew and Luke. But it is its spirit rather than its mere language which he reproduces, and for this deeper relation he cannot have been solely dependent on this single fragment of $\mathbf{Q}$ material. Light dawns when we discover the logion to be one of many hymns of Wisdom, whose common root is the idea of Israel as the People of Revelation. For (as stated in the article referred to) "To be the Son of God by knowing and doing his will is the Pharisee's ideal for his people." Indeed, however unique the terms 'Son' and 'Father' may sound in modern ears in this application, they are in reality the characteristic generalities of Lyric Wisdom. A series of Jewish parallels will disclose the facts; for the logion in its fundamental ideas, if not in actual composition, is certainly pre-Christian.

A preliminary look at certain contemporary pagan conceptions will be desirable; for the literature of theosophic mysticism exploited by Norden has much light to throw on the logion, as a typical utterance of the many "revealers of the Unknown Father."4

Plato himself willingly avowed dependence on the "revelations" of Orphic poets. Plutarch's search for "the oldest" religion shows the same wide-spread idea of an original divine revelation dissipated among the

- The phrase is typically Gnostic. Cf. Cerinthus, ap. Irenaeus, Haer. I, xxvi, 1, as quoted below. 
world's many religions. The various mysteries and cults of the Empire were exploiting this idea to the utmost, as Reitzenstein and Cumont set forth. But Norden has told us very little of the Jewish adaptation of the idea. That it should be seized upon both in Palestine and Alexandria was inevitable. Nothing could be more congenial to the thought of this people, whose sole hope and distinction was its unique religious literature, than the ideal of Israel as mystagogue of the nations, the people of revelation, of torah, or, as the Greek would say, of gnosis. And this adoption has a vital bearing on the interpretation of the $\mathbf{Q}$ logion. Its key-words are the terms 'Son' and 'Father,' and while Norden has fully illustrated the employment of these in the literature of pagan mysticism he has passed over much that was at least equally instructive in the literature of contemporary Jewish mysticism. Thus in pagan mysticism 'Son' is the term for the recipient and transmitter of the revelation, the $\mu \dot{v} \sigma \tau \eta s$ of the mystery religions. In Lyric Wisdom the Son is Israel, chosen as the predestined organ of divine revelation to the world. Israel is the world's hierophant, the Son that is "known" of God in order that he may make God known.

Two postulates are indispensable to right understanding of the facts. We take them respectively from Norden and from R. H. Charles.

(1) The logion is primarily concerned with the claim of the Son (i.e. in the evangelist's understanding, Jesus) to be the mouth-piece of divine revelation. It deals

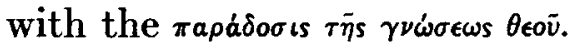

Norden's parallels are here decisive. He summarizes for example the typical Hermetic 'Thanksgiving' as follows:

"I believe and testify. Praise to thee, Father.

Thou transmittest to me, thy son, the whole fulness of thine authority.

For thou didst reveal thyself and thus becamest known. 
This knowledge at thy command I transmit to my fellowmen who are worthy.

The unworthy harden themselves against it." 5

The agreement of this schematic form with the logion is obvious, and the coincidence in substance is mutually illuminating.

(2) The title 'the Son' in Jewish literature is messianic, and like all the messianic titles, Servant, Son, Beloved, First-born, Only-begotten, Elect, Saint, Just One, \&c., is of primary application to Israel collectively. Israel is the 'Son,' 'First-born,' \&c., whom Jehovah elected to adoption and brought out of Egypt. The application to the Messiah, as representative of Israel, Jehovah's agent in accomplishing the national destiny, is secondary. This principle has been so clearly stated by R. H. Charles, and is so well established, that we may properly build upon it. As classical examples of the application to Israel of the particular titles First-born, Only-begotten, Beloved Son, we may refer to 2 Esdr. 658 and Pirke Aboth, iii, 19. On these titles and their significance more hereafter. We have first to consider the limits of our material.

It is gratifying to obtain the support of Norden against two such eminent authorities as Wellhausen and Harnack for the authenticity of the received text. On purely internal grounds Wellhausen had argued against the authenticity of clause $b$ of Strophe II, "No man knoweth the Son save the Father." This he declared irrelevant and interrupting. Harnack had reenforced the objection ${ }^{6}$ by citing a single variant, the Old Latin codex $a$, which in Luke (not in Matthew) has the reading: "Omnia mihi tradita sunt a patre, et nemo novit quis est pater nisi filius, et cuicumque voluerit filius revelavit." This unique variant of the Old Latin

Op. cit., p. 293.

- Evang. Matthaei, Berlin, 1904, p. 57 f. Harnack, Sprüche u. Reden, p. 204. Per contra, Bacon, op. cit., $\$$ iv. 
has the value of proving how the Western mind experienced in ancient times the same sense of interruption of the context which leads Wellhausen to reject the clause. But it has no other value, and in view of many parallels it will be apparent that the difficulty is with the Western mind and not with the text.

On the point of relevancy (which must be judged not from our point of view, but the writer's) the parallels are decisive. We may take first those already cited in the essay referred to as "examples from the Pauline writings (Gal. 4 9; 1 Cor. 13 12; 2 Tim. 2 19), which show what was the primitive treatment of the complementary principles of 'knowing' and 'being known of' God."' In Gal. 49 the same antithesis is employed concerning the Adoption of the Spirit. By it we come "to know God, or rather to be known of God." That is, the relation of sonship is not an acquisition of human wisdom, but an election, or adoption, a gracious admission by God into the confidential relations of $\mathrm{His}$ household. The verb to 'know' is used in this pregnant sense of 'recognize,' 'acknowledge,' in 1 Thess. 5 12, "We beseech you to know them that labor among you, and are over you." So in 1 Cor. 1312 the ideal gift of gnosis is "to know even as I have been known." Previously in the same epistle ( $82 \mathrm{f}$.) we have a similar subordination of the 'knowledge' of God ( $\gamma \nu \bar{\omega} \sigma$ is $\theta \epsilon o \bar{u})$ to the greater gift of 'love,' with the same contrast of the terms 'knowing' and 'being known' of God: "If any man seemeth to have attained 'knowledge' ('́ $\left.\gamma \nu \omega \kappa^{\prime}{ }^{\prime} \nu a \iota\right)$ of anything, he hath not yet come to 'know' (๕̌ $\gamma \nu \omega)$ as he ought. But if any man love God the same hath been 'known' (' $\gamma \nu \omega \sigma \tau a \iota$ = adopted into the relation of familiaris) by Him.""8

To these Pauline parallels to the antithesis of 'knowing' and 'being known' of God a few may now be added which tend to show that the idea of adoption vs. gnosis is

7 IV. Knowing and Being Known of God. Reprint, p. 16.

${ }^{8}$ Cf. Lk. 747. 
part of the general Jewish insistence upon its own divine Election (under the condition of obedience) over against heathen religion or philosophy. Thus the Pauline thought of 1 Cor. $82 \mathrm{f}$. is closely reproduced by the Johannine writer in $1 \mathrm{Jn}$. $47 \mathrm{ff}$. in protest against a doctrine of salvation by gnosis apart from obedience to the one 'new commandment': "Beloved, let us love one another, for love is of God, and everyone that loveth is 'begotten of God' and 'knoweth' God" ( $(\gamma \iota \nu \dot{\omega} \sigma \kappa \epsilon \iota$ $\partial \dot{\nu} \nu \theta \dot{\theta} \dot{\nu})$. Like Paul, moreover, this writer keenly emphasizes the priority of the divine Election: "Herein is the love, not that we loved God, but that he loved us, and sent his Son, \&c. . . . We 'know' and have believed the love which God hath in our case. God is love, and he that abideth in love abideth in God and God abideth in him. . . . We love because he first loved us." And this doctrine is not exclusively Johannine nor even exclusively Christian. Ode iii of the Odes of Solomon gives expression to the same thought on behalf of Israel, God's Beloved:

"On His members do I hang, and He loves me.

For I should not have known how to love the Lord if He had not loved me.

For who is able to distinguish love save the one that is loved?

I love the Beloved, and my soul loves Him."

And the odist adds, as if in express denial of the pretensions of heathen gnosis:

"This is the Spirit of the Lord which doth not lie.

Which teacheth the sons of men to know His ways.

Be wise and understanding and vigilant. Hallelujah."

The closing line has the typical exhortations of contemporary religious mysticism ( $\left.\sigma \omega \phi \rho o v \dot{\eta} \sigma a \tau \epsilon, \nu \dot{\eta}^{\prime} \sigma a \tau \epsilon, \nu \dot{\eta} \psi a \tau \epsilon\right)$; but Ode iv, 9 is perhaps closer still to $1 \mathrm{John}$ :

"Thou hast given us thy fellowship.

It was not that thou wast in need of us, but that we are in need of thee." 
Of the Odes of Solomon and their Jewish theme of Israel as the people of revelation, God's Chosen and Beloved, entrusted with his torah (i.e. 'teaching'), we shall have more to say presently. The Jewish mystic's affirmation is that the true gnosis rests solely on a divine Election in love by sovereign grace. With the destruction of Israel's political ambitions, and the substitution after the Exile of the Isaian ideals of the Servant bringing an evangelized world to the worship of Jehovah, the idea of the prerogative of Sonship necessarily underwent a change. The proof of it is found in Israel's special revelation, in written or unwritten torah, in the Spirit of the divine Wisdom abiding with the Servant, fitting him for his world-redemptive task.

From this age-long Jewish sense of Israel's divine prerogative, an adoption in love to be a revealer of the Father to a darkened world, springs both the Pauline and the Johannine gnosis. The relation of filial loveobedience to the new commandment-this and not purblind philosophy qualifies Jehovah's messenger. The Johannine point of view, like that of Paul which it reproduces, is therefore not merely Christian, but (in Jewish form) pre-Christian. It appears no less clearly in the Johannine Gospel than in the Epistle, as e.g. Jn. 15 11-15, where the confidential relation of the "friend who knoweth what his lord doeth"9 is contrasted with the slave's. Here again election and obedience are the real theme. Moreover the succeeding verses (16 f.) emphasize as before the priority of the divine choice ("Ye did not choose me, but I chose you," \&c.), and insist on the condition of obedience to the commandment of love (ver. 14, 17). Similarly in Jn. 8 31-59 the debate concerns the claim of the Jews to be Sons of God (ver. 41) by having knowledge of the truth (ver. 31 f.). Against this, as in Gal. 4 21-5 1, freedom and

' Cf. Sap. 7 27: "Wisdom ... entering into holy souls makes men to be friends of God and prophets." 
sonship are claimed for Christians only. They will "abide in the house" as true heirs of Abraham when the "bondslaves" are cast out. The claim of the Jews to be Abraham's sons is as false as their pretense never to have been in bondage. Their murderous purpose proves them sons of Satan and slaves of sin. The Johannine contention is that the election to sonship is through gnosis; but that this 'knowledge' is morally conditioned. The dialogue has indeed more real connection with the logion than Jn. 10 15, which Norden cites.

It recalls the protest of 2 Tim. 219 (a writing of the same region and period) against a similar non-moral gnosis. The Paulinist uses two complementary 'faithful sayings' as the 'seal' engraved on the foundation of God. The two-fold basis of God's building is: (1) divine election (2) human obedience. On the divine side: "The Lord 'knoweth' them that are his"; on the human: "He that nameth the name of the Lord, let him depart from iniquity." As against 'sons' who profess to 'reveal the unknown Father' by virtue of acquired gnosis, the 'Son' (whose good works support his claim) relies upon a divine election. None hath known (acknowledged) him save the Father who 'foreknew' and predestined him in His own eternal 'good-pleasure.'

But clause $b$ of Strophe II also asserts on the negative side the world's ignoring of the bearers of divine revelation. In reality this is but another aspect of the familiar plaint of Wisdom at men's senseless refusal of her, a literary form as old as the prologue of Heraclitus. If Wisdom be spurned (as experience proves but too often the case), it can only be in the person of her exponents and representatives. Hence in Deutero-Isaiah and the kindred psalms of complaint of national ill-treatment, such as Ps. 22, ${ }^{10}$ the Servant is both witness and martyr.

${ }^{10}$ For the close connection of this and kindred Psalms of Martyrdom with the Deutero-Isaian songs of the Suffering Servant, see Cheyne, The Prophecies of Isaiah (1884), II, pp. 208-204. 
Wisdom of Solomon tinctures the Isaian figure of the Servant with colors borrowed from the persecuted "wise man" of Plato's Republic and the Stoic ideal Wise man who witnesses before an unheeding world. This plaint of Wisdom is a normal development in lyric Wisdom, including the Odes of Solomon, of the Isaian theme of the Servant "whom man despiseth, whom the nations abhor." A1 A typical Wisdom plaint is taken up in the form of a logion of Jesus in the Oxyrhynchus Fragment (Log. IV). Here it was originally Wisdom, but Wisdom incarnate in the person of the bearer (or bearers) of divine revelation, who complained:

"I stood in the midst of the world

And in the flesh was I seen of them ${ }^{12}$

And I found all men drunken

And none found $I$ athirst.

And my heart was grieved for the children of men

Because they are blind in heart and see not,

Poor, and know not their poverty."

The adoption of the plaint as a saying of Jesus is paralleled in the Wisdom plaint of Lk. 11 49-51; 13 $34 \mathrm{f} .=$ Mt. 23 34-39.

The world's ignoring of the messenger is likewise a theme of the Odes of Solomon, as for example xxx, 6, which says of "the fountain of the Lord":

"It came infinitely and invisibly,

And until it was set in the midst men did not know it."

To contemporary Jewish feeling, accordingly, the world's ignoring of the bearer of divine revelation is not irrelevant. On the contrary, it is complementary to the 'knowing' (i.e. admission to intimacy) of the Son by the

${ }^{11}$ Is. $497 ; 506 ; 533$; cf. Sap. $212-39$; and Odes xxviii and xxxi.

$12 \mathrm{Cf}$. Bar. 337 of the incarnation of Wisdom in Israel. The verse is suspected, though already quoted by Irenaeus. But no suspicion attaches to Sap. 6-9; 1016 , \&c., where Wisdom "enters the soul" of Moses, Solomon, and other "friends of God and prophets," and makes Israel the chosen "Son" her abiding-place. 
Father. The election in the 'good-pleasure' is expressed in the phrase of Am. 32, "You only have I known of all the families of the earth." Its complement is to be "despised and rejected of men."

From the period of Deuteronomy and Deutero-Isaiah the election, or adoption, of Israel is constantly declared to be for the purpose of extending knowledge of the true God to all the nations. The Servant was chosen and filled with Jehovah's Spirit for the purpose of 'witnessing' for Him, and "to bring forth true religion (mishpât) to the Gentiles" (Is. 42 1-4). He receives the title of Jehovah's "First-born," originally applied in a different sense (Ex. 4 22 f.), because of his adoption to this special function of 'witnessing,' and in view of his destination to be the Heir. This conception is chiefly developed as we might expect in the Wisdom literature. Indeed the later Jewish literature, both Alexandrian and Talmudic, takes this title of 'First-born' in a transcendental sense of predestination before the creation. Israel was fore-known before the foundation of the world and chosen from all eternity. The world was created on Israel's account, other nations being admitted to jointheirship only as younger sons, and through Israel's mediation. It is in this sense that the Odes of Solomon claim not merely priority for Jehovah's chosen sanctuary of Zion before other sanctuaries, on the ground that He designed it "before He made places," 13 but priority of origin for Israel over Gentile peoples. Israel is persecuted and hated in spite of its philanthropic mission to the Gentiles, but

"I did not perish, for I was not their brother nor was my birth like theirs,

And they sought for my death and did not find it; for I was older than the memorial of them.

And vainly did they make attack upon me and those who followed me. 
To no purpose they sought to destroy the memorial of him who was before them.

For the thought of the Most High cannot be forestalled And His heart is superior to all cunning. Hallelujah." ${ }^{14}$

Moreover when Israel has fulfilled its mission of glorifying Jehovah before the world, He also will glorify them. Thus the 'knowing' of the Son is not merely as in Psal. Sal. xvii, 30, that Jehovah "takes knowledge of them that they be all the sons of their God," but this being 'known' becomes a formal acknowledgment in the presence even of angels. Thus in Jubilees 1 25,

" They all shall be called children of the living God and every angel and every spirit shall know, yea they shall know, that these are my children and that $I$ am their Father, in uprightness and righteousness, and that $I$ love them."

In Christian form this becomes a divine acknowledgment of "the adoption" in the presence of "the principalities and powers in the heavenly places." The eternal purpose of God is made known to these proud powers "through the church." In Rom. 8 15-21 the "manifestation of the sons of God" is the goal and dénouement of the creative mystery; earthly and supernal powers seek in vain to separate the "heirs" from the goal of His redeeming love. ${ }^{15}$

The need to vindicate the clause "No man knoweth the Son save the Father" as authentic has led us to anticipate. The parallels, Jewish and Christian, do more than prove its relevance. They show how the Jewish consciousness of higher religious insight had laid hold of the current mystic phraseology of gnosis to base upon it the claim to a national election, a sovereign act of the Creator's foreordaining love, a pre-creative divine placuit or good-pleasure (rātsōn, єujokia). To the Jew this Son

14 Ode xxviii, 14-18; cf. xli, 8 f.

${ }^{15}$ Rom. 8 33-39 employs Is. 508 f. With this compare Ode Sal. xxviii, 5 f. and Eph. 310 f.; 6 12; Col. 215. 
who alone knows the Father is Israel, the people of revelation. Israel's gnosis, however, is not the wisdom of Gentile philosophy, but a gracious revelation bestowed by God on the 'beloved' people who though despised and ignored by the world are 'known' by Him as His 'witnesses.' For the revelation of the Father has its purpose. It is not for the Son alone, but for him also "to whomsoever the Son willeth to reveal Him." As between Jew and Christian the question is only as to which exhibits that filial disposition which justifies a relation of "love."

But a further question still affects the limits of our material. Strophe III of the Ode (Mt. 1129 f.) fails to appear in the Lukan parallel. It is that which Norden designates "The Appeal to Men," very properly adducing as parallels the exhortations of Wisdom in the Wisdom lyrics generally, but especially Ecclus. 51-52, and of the "pure virgin" in Ode xxxiii of the Odes of Solomon.

In § III of the Essay already referred to (p. 13) the present writer yielded to the more conservative critical judgment which excludes Strophe III from the common source $(\mathbf{Q})$, mainly because grounds for its omission by Luke are difficult to define. Norden now advances strong reasons for regarding it as a genuine stanza of the hymn. This, however, is not decisive as to its having been contained in the Second Source, a fundamentally Christian writing. For if the poem be an excerpt from some unknown 'Wisdom' ode like the 'Wisdom' excerpt Mt. 23 34-39=Lk. 1149 f.; 1334 f., it is quite conceivable that our first evangelist should have restored its missing stanza from the original (Jewish) source, just as Lk. $35 \mathrm{f}$. supplies from Is. $404 \mathrm{f}$. the remainder of the sentence given in truncated form by Mk. 1 3. But first as to authenticity.

Norden's division by kola and kommata is not arbitrary but is dictated by the sense, and Strophe III corre- 
sponds in all respects with Strophes I and II. This symmetry of structure (cf. e.g. Ps. 23 in Intern. Crit. Comm. p. 207), and the fact that the coincidences with Ecclus. 51 cover not only Strophe III but also Strophe I (cf. Ecclus. 51 1-12 '̇ं give irresistible evidence that Matthew's fuller form is the more authentic. This will be true whether Luke or the Second Source be responsible for the omission, a point on which Norden's opinion is difficult to make out. True, he says (p. 301):

"The question whether Strophe III of the logion, which does not appear in Luke, belonged to the $\mathbf{Q}$ source, a question designated in the more recent discussions as still unsettled or unanswerable, is to be answered unconditionally in the affirmative."

But the only reason given is that

"the appeal which it contains forms a stereotyped element of the literary model."

This argues for authenticity in the Ode, but not necessarily in Q; for Norden adds quite frankly, "I cannot say for what reason Luke omitted this portion of his source," and (as we have seen) it is quite supposable that Luke gives all that his immediate source - the $\mathbf{Q}$ source - contained, while Matthew's addition of Strophe III might be a restoration from the original (Jewish) Wisdom hymn.

The point of chief importance, however, is that the original hymn contained all three strophes, each containing four corresponding lines; for (as Norden's parallels show) the normal form of the Wisdom song of this type is three-fold: Strophe I, Thanksgiving for the 'Evookia; Strophe II, Reception of the $\gamma \nu \tilde{\omega} \sigma \iota ;$ Strophe III, Appeal to Men.

But once we bring under consideration the Christian and pre-Christian parallels to these three elements of the 
hymn, its original application to Israel as the People of Revelation becomes unmistakable.

The distinctive feature of the Jewish doctrine of election as understood in lyric Wisdom is the divine 'goodpleasure' and this it is which is celebrated in Strophe I

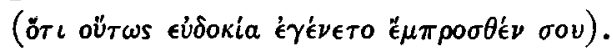

According to the Deuteronomist, Deutero-Isaiah, the Wisdom writers, and the later synagogue generally, this good-pleasure of God was, as we saw, an election of Israel to be the people of torah, i.e. the revelation of God embodied in the Law.

“This (says the Deuteronomist) is your wisdom, and your understanding in the sight of the peoples, that shall hear all these statutes and say, 'Surely this great nation is a wise and understanding people.' For what great nation is there that hath a god so nigh unto them as Jehovah our God is whensoever we call upon him? And what great nation is there that hath statutes and ordinances so righteous as all this law, which I set before you this day?" 16

The purpose of this choice of Israel and its endowment with torah is that all the ends of the earth may come to know Jehovah and to swear by His name. This people is designated His Servant; they are His 'witnesses' against the worshippers of idols, His 'messengers' to all far-off lands to proclaim the name and praise of the Maker of heaven and earth. This is the supreme message of Deutero-Isaiah. The chief difference between its development in the Wisdom literature (representing in the main the propaganda of Alexandria) and the Palestinian development under the scribes is that under the favoring auspices of Ptolemaic rule the Isaian ideal became liberal and $e x$-tensive, so that Israel's endowment was considered to be the living Spirit of the divine Wisdom, and Israel's calling the propagation of this gnosis; whereas in Palestine the bitter struggle against Hellenizing persecution compelled a more narrow and 
in-tensive development, Israel's endowment being defined as the written Torah, and its calling to 'witness' becoming primarily a calling to martyrdom.

On the particular point of the mystery of the meaning and purpose of the creation a parallel between two nearly contemporary documents, one Jewish, the other Christian, will show the nearness of the relation. We may follow it with a few from rabbinic sources and from lyric Wisdom:

Assumptio Mosis 1 12-14 (7-30
A.D.).

"The Lord of the world hath created the world on behalf of His people. But it was not His 'good-pleasure' to reveal this purpose of creation from the foundation of the world, in order that the Gentiles might thereby be convicted, yea to their own humiliation might by (conflicting) arguments convict one another. Accordingly $\mathrm{He}$ designed and devised me (Moses), and He prepared me before the foundation of the world that $I$ should be the mediator of His covenant (of the Inheritance)."
1 Cor. 1 20-3 1 (in abstract).

"For seeing that in the wisdom of God the world through its wisdom knew not God it was God's 'good-pleasure' to save believers through the foolishness of the preaching. . . . We speak God's wisdom in a mystery (revelation), even the hidden wisdom which God foreordained before the worlds unto our glory, which none of the (angelic) 'world rulers' hath known, but as it is written (quoting an unknown lyric source),

'Things which eye saw not and ear heard not

And which came not up into the heart of man,

Whatsoever things God prepared for those that love Him.'

But unto us God revealed them by the Spirit; for the Spirit searcheth all things, yea the deep things of God. . . . Which things also we (preachers) speak, not in words which man's wisdom teacheth, but the Spirit. . . . I spoke unto you as to 'babes' in Christ. I fed you with milk." 
The literary affinity of 1 Cor. 1 18-3 1 with the $Q$ logion has long been apparent, Pfleiderer and Harnack being among those who call attention to it. But the real point of connection is not with $\mathbf{Q}$, where the application is to Jesus personally, but with the Hymn in its pre-Christian sense, where (as in Paul) God's people are the true hierophants as against the wisdom of "the (Gentile) world."

The doctrine that God created the world as an inheritance for his chosen and beloved people is, in fact, a commonplace of the later Jewish literature ( $c f . e . g$. 2 Esdr. 6 55-58 and Apoc. Bar. xiv, 18 f.) which rests upon Gen. 1 24-26 and passes over into Christian teaching with a minimum of change (Rom. 4 13; 1 Cor. 3 22; Rev. 21 7; Hermas Vis. ii, 41 \&c.). The Assumptio Mosis, as we see, boasts of the revelation of this secret to Moses over against the vain speculation of Gentile philosophers. Paul contends, however, that the Christian preacher possesses in 'the Spirit' the creative wisdom itself; 1 " for this, to Paul, is "the mind of Christ" and it knows the purpose of God "even as the spirit of a man knows what is in him." Thus the Christian evangelist becomes the true mystagogue. He reveals to the world the secret purpose of creation - "even the things which God prepared for them that love Him." This mystery was hid from former generations (Rom. 1625 ; Eph. 3 3-5, 9-11) and even from angels (cf. 1 Pt. 112 and Slav. Enoch xxiv, 3), but is now revealed to God's holy apostles and prophets in the Spirit, and is ministered by them as 'milk' to 'babes.' 18

This is not mere self-exaltation on the part of Paul and his fellow-preachers. His quotation of an unknown "scripture" shows that he is simply appropri-

${ }^{17}$ Cf. in 2 Cor. 3 4-4 6 a similar comparison of the "ministry of the new covenant," and its revelation of the "gnosis of the glory of God in the face of Jesus Christ" with the revelation to Moses at Sinai.

${ }^{18} \mathrm{Cf}$. Odes of Sol. viii, 17; xxxv, 6, \&c. 
ating the religious function of Israel according to the flesh for "the Israel of God." Akiba the martyr-rabbi and founder of Talmudic Judaism scarcely more than a generation later shows us the common basis. $\mathrm{He}$ is vindicating Israel's claim to be the Elect People, the Beloved Son, against both Christian and pagan gnosis, and makes a characteristic appeal to Scripture. All men in a sense are God's 'sons' (Mal. 2 10). All can in a sense claim His 'love.' But Scripture discriminates. Only Israel, the people gifted with torah (revelation), is in the highest sense God's 'Beloved Son.' This is the substance of Akiba's condensed argument from Gen. 9 6, Dt. 14 1, and Prov. 4 2, as given in Pirke Aboth iii, 19:

"Man is 'beloved' in that he was 'created in the image' (of God). But greater love is shown in the revealing to him that he was 'made in the image.' As it is said, 'In the image,' \&c.

"'Israel are 'beloved' in that they are called 'sons of God.' But greater love is shown in revealing to them that they were called sons of God, as it is said, 'Sons are ye to the Lord your God,' \&c.

"Israel are 'beloved' in that to them was given the precious instrument wherewith the world was created (the divine Spirit of Wisdom). But greater love is shown in revealing to them that to them was given the precious instrument wherewith the world was created, as it is said, 'I have given you a good doctrine. Forsake ye not my torah,", \&c.

It is in the context of the last-named passage (Prov. 42 f.) that Akiba finds the titles 'Son' and 'Beloved,' which he claims in a unique sense for Israel, and claims them on the ground of revealed knowledge with particular reference to the creation. In Prov. 43 Israel is in fact addressed (by the divine Father according to Jewish interpretation) as 'Son,' and not only so but as God's "Beloved" and "Only-one" or "Only-begotten," as the Hebrew is rendered in the related passage 2 Esdr. 658. 
We are here at the point of coincidence between Alexandrian Wisdom and rabbinic Judaism. For both these the election of Israel is an election to be the people of torah, their predestined function is to reveal Grod to the world. He is the Unknown Father. They are His 'only' Son, whom $\mathrm{He}$ chose in love before $\mathrm{He}$ founded the world, that they might reveal Him to such as are worthy. Hellenistic and Talmudic Judaism diverge in proportion as this endowment with torah is understood predominantly of the letter which killeth or the Spirit which giveth life. It is impossible to invert the relation and imagine that the Jewish conception of the Beloved Son who is chosen that he may reveal to the world the Unknown Father is borrowed from Christianity.

Appreciation of the significance and development of lyric Wisdom has received of very recent years an enormous impetus through the discovery of the Odes of Solomon. Whether they be fundamentally Jewish with merely superficial Christian adaptation (as the present writer still maintains), or Christian from the foundation, is a debated question. Even their date can only be determined as within about a century before or after 100 A.D. But both title and contents should at least make this point clear: The Odes of Solomon belong distinctively to lyric Wisdom, and have their basis in Jewish ideas. Their supreme value is that they enable us to trace the development of the Deutero-Isaian ideal of Israel as the Servant-Son, witness and martyr, through the Songs of Wisdom as known in Ben-Sirach, Wisdom of Solomon, Baruch, and elsewhere, down to and even beyond the dividing line of Christian Logos doctrine. Surely one of the first problems to which this great influx of new light should be applied is the problem of the great logion of the Son's revelation of the Father, the Hymn of Thanksgiving of the $Q$ source. 
If then we take first the subject of Strophe I of the logion, Jesus' thanksgiving for the 'Evooria, it should be apparent to all who have any familiarity with the Odes of Solomon that the theme is coincident. The opening poems exult in the election of the 'Son' as the Lord's 'Beloved,' the sharer of His 'secret,' His 'planting,' and the 'ministers' of the 'river' of His Spirit.

In the present Christian editorial adaptation of the Odes the speaker who constantly refers to himself as the 'Son,' the Lord's 'Beloved,' \&c., and habitually employs the first person, might easily be taken for the individual poet. In spite of the entire absence from the Odes of any mention of the name of Jesus it is clear from the redaction that the poems have been given this individual application. But this ignores all the classic examples of Hebrew religious poetry. So familiar an instance as Ps. 23, whose theme is Jehovah's shepherding of Israel ( $c f$. Is. 499 f.), or Ps. 18, celebrating Israel's deliverance in the Red Sea and conquest of Canaan, ought to teach us how constantly in Hebrew psalmody the personal pronoun in the first person singular has primary reference to Israel. The poet sings in the name of his people.

This is equally the case with lyric Wisdom, where Ecclus. 24 30-34 may serve as an example, and no less in Odes i, iii, and vii of the Odes of Solomon, which celebrate respectively the Crowning of Israel with the living Garland of divine Truth, its Union with Jehovah as his Beloved, and its Endowment with the Word of Knowledge. To make this certain we must scrutinize the imagery in the light of contemporary literature.

The Mishna, interpreting the Song of Songs, which is Solomon's, declares that "the day of espousals" (Cant. 3 11) was that of the giving of the Law at Sinai. This refers to a wide-spread tradition which explains the vows of the people's covenant to keep the law (Ex. $247 \mathrm{f}$.) as vows of betrothal to Jehovah. Accordingly 
the stripping off of the ornaments to make the golden calf is interpreted to mean the stripping off of "the golden crown that was upon their head, whereon the NAME had been engraven and set forth at Mount Horeb." ${ }^{19}$ Pesilta thus connects Ezek. $1612 \mathrm{ff}$., "I put a crown of beauty upon thy head," \&c., with Ex. 24 7, and declares that when Israel accepted God's law "God gave them of the brightness of the Shechinah." The "crown of the law' becomes thereafter a classic phrase for rabbinic Judaism to designate the knowledge of God which is at once Israel's supreme adornment and (like the bride's tiara) the token of loving obedience to her Lord. The 'brightness of the Shechinah' which is upon it makes it a "crown of light," in the Coptic paraphrase (Pistis Sophia 115-16), and this perhaps accounts for the references in the Odes (e.g. xlii. 11) to the sign or seal of 'the light' as set upon God's Beloved, and references to it in Talmudic literature as "brightness from the Shechinah," and in Wisdom as a "crown of glory."

But the Odes present the usual contrast of the symbolism of the sages with that of the scribes. The "crown of life," or "of glory," which the Lord promised to "those that love him" (Jas. 1 12) soon becomes a commonplace of the Wisdom literature, as in Sap. $516 \mathrm{f}$. the righteous are promised "the royal crown of comeliness and the diadem of beauty from the hand of the Lord." But this is a weakening down of the Isaian original, in which (Is. 28 5) the Lord himself becomes "a crown of glory and a diadem of beauty to the residue of his people, a spirit of justice to its judges and a spirit of strength to its warriors." The Spirit of Jehovah suspended over His sanctuary like the pillar of fire and smoke above the altar ${ }^{20}$ will be a living unfading chaplet in contrast with the fading wreaths on the heads of the drunkards of Ephraim. Wisdom's 
song in Prov. 4 1-9 comes nearer this meaning, for Wisdom is the 'mother' that loves her sons, and keeps those that love her, of whom it is promised:

"She will give to thy head a chaplet of grace,

A crown of glory will she deliver to thee."

But only Ode $\mathrm{i}$ of the Odes of Solomon goes straight to the primitive Isaian sense, making Israel's living crown the Spirit of the Lord which gives knowledge of Himself. Only as speaking for Israel gifted with the torah of God can the Odist declare:

"The Lord is upon my head as a crown

And apart from Him I shall not be.

They wove for me the crown of Truth

And it caused Thy branches to bud in me.

" For it is not like a withered crown that buddeth not, But Thou livest upon my head and hast blossomed on my head. Thy fruits are full and perfect, full of Thy salvation."

The remainder of Ode i, all of Ode ii, and the beginning of Ode iii are unfortunately wanting. What remains of Ode iii easily proves it a Song in the vein of Canticles, a book always interpreted from the time of its reception into the canon as a nuptial song of Israel (in Christian interpretation, the Church) as Jehovah's Beloved and supposed to have been written by Solomon, to whom David had given the name Jedidiah, i.e. 'The Lord's Beloved.' From Ode iii we have already taken a parallel to the Pauline and Johannine doctrine of the 'sovereign grace' of the Election,"1 an election whose purpose is to "teach the sons of men to know Grod's ways." We need only note that Baentsch's rejection as the gloss of a Christian scribe of the single word "the Son" in the line

"Because I shall love Him-the Son-I shall be a son," 
is regarded by Harnack as indisputable. ${ }^{22}$ Certainly God and not "the Son" is the object of the love expressed in the Ode.

More akin to the thought of Strophe I of the New Testament hymn is Ode vii, a thanksgiving for endowment with the divine Spirit of Wisdom as the Way to God. We have space to quote but a few strophes:

" He (God) hath caused me to know his soul without grudging in His singleness, ${ }^{23}$

For His loving-kindness hath made small His greatness.

Like my nature He became that I might learn to know Him, And like my form that I might not turn away from Him.

"The Father of knowledge is the Word of knowledge. He that created Wisdom is wiser than His works, And He that created me knew when as yet I was not What I should do when I came into being.

"For to knowledge He hath appointed its way.

He hath broadened and lengthened it and made it come to all fulness, And He hath set upon it the footprints of His light, And I have gone (therein) from the beginning to the end..$^{24}$

"For from Him it ( $\gamma \nu \bar{\omega} \sigma$ cs) was wrought, and it hath rest in the Son. And for the sake of their redemption he (the Son) will lay hold upon all things,

And the Most High shall be known through His saints

To bring [the good] tidings to such as have psalms of the Coming of the Lord."

The strophe which tells of the condescending lovingkindness of the Lord in making Himself known gives at first the impression of a reference to the incarnation of Christ; but the impression is misleading, for as the poem proceeds it becomes evident that it is the Creator and

${ }_{22}$ Meines Erachtens sicher.

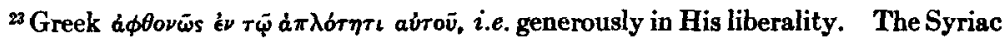
has taken $\dot{a} \pi \lambda \dot{b} \tau \eta \tau \iota$ literally as in Mt. 622. Father."

$2 \mathrm{Cf}$. the claim of the revealing "Son," "All things are delivered to me of $\mathrm{my}$ 
Father of Wisdom - terms impossible to imagine applied to Christ by any writer of this period - of whose condescension the odist sings in the vein of Ps. 138, and Is. 5715 and $661 \mathrm{f}$., while the revealing Son is seen in the closing lines to be "the people of the saints of the Most High." But even were it granted for argument's sake that the poem is a wholly Christian product, we are not so much concerned with the product as with the material; and the material, the basic ideas of election and predestination to the function of Leader in the Way of God for the redemption of the world, can be proved over and over again to be the prerogative of Israel, the revealing Son in pre-Christian lyric Wisdom.

In the Ode the speaker to whom God has stooped "that I might not turn away from Him" proceeds to refer to his own election in the divine foreknowledge. God has entrusted him with all the Way of gnosis. Its "rest" is "in the Son," who "takes hold of all things for their redemption." We shall need presently to enquire just what is meant by the 'resting' of Wisdom in the Son, but our first step should be to place alongside of Ode vii the Wisdom-song of Bar. 3 9-4 4, which similarly celebrates the Way of God whose keeping is committed to Israel:

"Hear, 0 Israel, the commandments of life;

Give ear to understand wisdom.

Thou hast forsaken the fountain of wisdom;

For if thou hadst walked in the Way of God

Thou shouldest have dwelt in peace forever."

The poet then dwells upon the hiding of wisdom from the world in ancient and younger days:

"Younger men have seen the light and dwelt upon the earth, But the Way of knowledge have they not known Neither understood they the paths thereof." 
So further of the various great peoples of the past he repeats in turn:

"These did not God choose, neither gave He the Way of knowledge unto them;

So they perished because they had no wisdom,

They perished through their own folly.

Who hath gone up into heaven and taken her,

And brought her down from the clouds?

Who hath gone over the sea and found her,

And will bring her for choice gold?

There is none that knoweth her Way

Nor any that comprehendeth her path.

But He that knoweth all things knoweth her,

He found her out with His understanding.

He that sendeth forth the light and it goeth, He called it, and it obeyed Him with fear. ${ }^{25}$

"This is our God, none other shall be accounted of in comparison with Him

He hath found out all the Way of knowledge, and hath given it to Jacob His Servant

And to Israel that is His Beloved."

It is perhaps a later hand which attaches the ten concluding lines:

"This is the book of the commandments of God

And the Law that endureth forever.

All they that hold it fast obtain life,

But such as leave it shall die.

Turn thee, $O$ Jacob, and take hold of it,

Walk towards her, shining in the presence of the light thereof.

Give not thy glory to another

Nor the things that profit thee to a strange nation.

O Israel, happy are we;

For the things that are pleasing to God are made known unto us."

${ }^{26}$ These verses of Bar. $333 \mathrm{f}$. should be compared also with Odes of Solomon xii and xvi, 18-16. 
Paul in Rom. $106 \mathrm{f}$. applies the passage quoted from Deuteronomy by this poet (Dt. $3012 \mathrm{f}$.) to Christ who as the Wisdom of God reaches from the height of heaven to nethermost abyss. But to this we can only advert in passing. The point which now concerns us is that the idea of Israel's election as the Son, the Beloved of God who makes known the Father, revealing the hidden Way of light and life, is adoptive in Christian literature, and must therefore always be interpreted with reference to its derivation. This is eminently true of the image of the 'resting' of the (Wisdom-) Spirit in the Son, by which the Jewish poet expresses the doctrine of the plenary endowment of Israel with divine revelation as against its hiding from (or rejection by) the Gentiles.

It would be easy to multiply Jewish parallels from lyric Wisdom, especially from the Odes of Solomon, concerning God's hiding from the world of the mystery of creative wisdom, that He might convey it to "babes" for their 'redemption' to eternal life through the ministration of His Son (Israel) the Beloved. We should especially direct attention to Ode vi, on the River of the Water of Life which "spreads over the face of the whole earth and fills everything," ${ }^{26}$ Israel being "the ministers of that draught, who are entrusted with that water of His," and invite comparison with the Wisdom-ode of Ecclus. 24 30-34, where again the speaker is Israel, minister of the draught of water of life to all the nations.

Strophe II of the $\mathbf{Q}$ logion on the Son's revelation of the Unknown Father is especially susceptible of abundant illustration from these sources. But there is less need of this in view of parallels already cited in support of the clause, "No man knoweth the Son save the Father." Parallels to Strophe III, both from BenSirach and the Odes of Solomon, have been already cited by Norden. Such space as we may still claim will be better applied, therefore, to the elucidation through

20 Ode vi, 10, resting on Is. 119 and Ezek. 47. 
parallels both Jewish and Christian of the conception of the divine good-pleasure (єivoкia), the election of the Son to fulness of knowledge ( $\gamma \nu \bar{\omega} \sigma$ is). "I thank Thee for election to gnosis.... All gnosis is delivered to me as sole revealer."

Norden justly remarks ${ }^{27}$ that clause $a$ of Strophe II is a typical claim to complete gnosis. We have seen in what sense Paul repeats the claim on behalf of himself and his fellow-evangelists in 1 Cor. $26-16$, and may take occasion to supplement this by reference to the similar claim on behalf of all Spirit-endowed Christians in $1 \mathrm{Jn} .220,27$. The full endowment with gnosis here claimed on behalf of Christian preachers, and even of the brotherhood as a whole, is of course more directly claimed by primitive Christians in behalf of Christ, often with citation of Is. 11 2. The various charismatic gifts in the church are regarded as but partial endowments from the complete "mind of Christ." He was "full of grace and truth," and "of his fulness" all had received. The transfer was not begun in Christian literature. In Eth. Enoch xlviii, 1-xlix, 3 we already have the same transition with use of the same proof-text:

"In that place [the glorified Holy Land] I saw a fountain of righteousness which was inexhaustible; around it were many fountains of wisdom, and all the thirsty drank of them and were filled with wisdom, and had their dwellings with the righteous and holy and elect. . . . For wisdom is poured out like water, and glory faileth not before him ['the Anointed One'] for ever and ever. For he is mighty in all the secrets of righteousness, and unrighteousness will disappear as a shadow and have no continuance, because the Elect One standeth before the Lord of Spirits, and his glory is for ever and ever, and his might unto all generations. And in him dwells the spirit of wisdom, and the spirit of Him who gives knowledge, and the spirit of understanding and of might and the spirit of those who have fallen asleep in righteousness. And he will judge the secret things and no one will be able to utter a lying word before him; for he is the Elect One before the Lord of Spirits according to His good-pleasure." 
We shall have occasion presently to observe how this conception of the whole fountain of gnosis being committed to Israel and its Messiah passes over into Christian thought, but our present task is to show that the "resting" of the divine Spirit of Wisdom in Israel as the chosen Son is of the very essence of the Jewish doctrine of Israel's election as conceived in lyric Wisdom.

We have already had occasion to quote from Odes of Solomon vii, 18, "From Him it (wisdom) was wrought and it hath rest in the Son," as a claim of Israel to possess all (redemptive) wisdom. The claim is in fact a commonplace of this literature from Ben-Sirach's Song of Wisdom down. In Ecclus. 24 $7 \mathrm{ff}$. Wisdom complains of her fruitless quest among the peoples for an abidingplace:

"With all these I sought rest,

And in whose inheritance shall I lodge?

Then the Creator of all things gave me a commandment

And $\mathrm{He}$ that created me made my tabernacle to rest,

And said, Let thy tabernacle be in Jacob

And thine inheritance in Israel."

As we have seen, Baruch $39 \mathrm{ff}$. also dwells upon the theme of Wisdom's finding no dwelling-place save in Israel, and even Talmudic literature presents its own characteristic variation on the theme in the legend of the rejection of 'the Law' by all other peoples, Israel alone welcoming it.

But Ben-Sirach's theme is itself only a development. In verses $10 \mathrm{ff}$. Wisdom continues:

"In the holy tabernacle I ministered before Him, And so was I established in Zion;

In the beloved city likewise He gave me 'rest."'

This is an elaboration of Ps. 132, where David sings as the ark is brought up from Kirjath Jearim: 
"Arise, O Jehovah, into thy 'rest,'

Thou, and the ark of thy strength.

For Jehovah hath chosen Zion,

He hath desired it for His habitation.

This (saith He) is my 'rest' forever,

Here will I dwell; for I have desired it."

Thus in lyric Wisdom the choosing of Zion as the 'resting-place' of Jehovah's spirit becomes coincident with the choosing of His First-born that the Spirit of Wisdom may 'rest' upon him in its fulness; and from an endowment of the elect people this inevitably becomes, both in Jewish and Christian thought, an endowment of Messiah their leader and representative.

It is in this Jewish doctrine of the plenary endowment of the elect people that we must trace the New Testament conception of the 'good-pleasure' which foreordains the Son as God's Beloved upon whom His Spirit 'rests.' According to Paul (Col. 1 15-20, 26 f.):

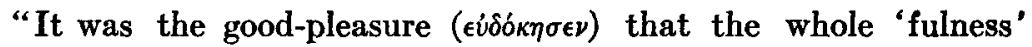

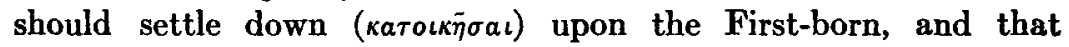

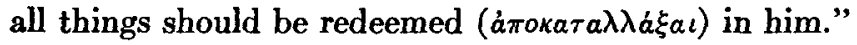

In Christ accordingly " are hid all the treasures of wisdom and knowledge." He is "the mystery (unveiled secret) of God." His spirit "in" the saints is a manifestation of "the mystery that hath been hid for ages and generations"; for in them as His witnesses "among the Gentiles" it is God's good-pleasure "to make known the wealth of the glory of this mystery."

What Paul means by the good-pleasure that the whole pleroma should settle down upon the First-born becomes apparent from the Gospel story of the descent of the Spirit upon Jesus at his baptism, with the Voice proclaiming the good-pleasure of the divine adoption (Mk. $110 \mathrm{f}$. and parallels). ${ }^{28}$ Especially clear does it

${ }^{28}$ On the meaning of the voice from heaven at the baptism declaring the divine election of the Son, cf. Bacon, art. "The Aorist $\epsilon \dot{\delta} \delta$ ó $\eta \sigma a$ in Mk. 1 11," Journ. of Bibl. Lit. xvi (1897). 
become in the peculiarly Jewish form of the story as quoted by Jerome from the Gospel according to the Hebrews:

"And it came to pass when the Lord had gone up out of the water that the whole fountain of the Holy Spirit descended and rested upon him and said to him: My son, in all the prophets I was waiting for thee that thou shouldst come and I should find rest in thee. For thou art my rest; thou art my First-born who shalt reign forever."

The fragment is employing the same passage (Is. 42 1) which forms the basis of the baptism story in the canonical Gospels, but whereas these clearly follow a text corresponding to Mt. 1218 ,

"Behold, my Servant whom I have chosen,

My Beloved, on whom my soul fixed her good-pleasure.

I will put my Spirit upon him,"

the uncanonical source follows a text corresponding to the Septuagint:

"Jacob my Servant, I will have compassion on him;

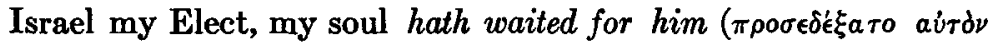
$\dot{\eta} \psi v \chi \dot{\eta} \mu o v) . "$

Jerome's knowledge of the Aramaic source is probably derived from the commentary on Isaiah of Apollinarios of Laodicea, who had lived among the Aramaic speaking Jewish Christian community of northern Syria which used this gospel; for Jerome (who knew no Aramaic) gives the quotation in his comment on Is. 11 2:

"And the Spirit of Jehovah shall rest upon himThe Spirit of wisdom and understanding,

The Spirit of counsel and might,

The Spirit of the knowledge and fear of Jehovah."

Great significance attaches in other Christian interpreters much earlier than Jerome to the word 'shall rest' (Heb.

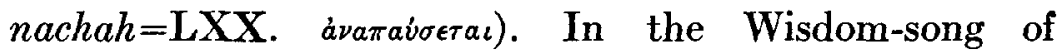
Ecclus. 24 5-7 it seems to have suggested the imagery of 
the dove seeking 'rest' for the sole of her foot and finding none until she returns to Noah ("man of 'rest"') in the ark. To Justin Martyr (Dial. lxxxvii) it signifies the finality and completeness of the endowment of Jesus with the gifts of the Spirit. Trypho the Jew asks:

" Tell me, then, how, when the Scripture asserts by Isaiah, 'There shall come forth a shoot from the root of Jesse . . . and the Spirit of God shall rest upon him, the spirit of wisdom and understanding, the spirit of counsel and might, the spirit of knowledge and piety and the spirit of the fear of the Lord shall fill him,' how he can be demonstrated to be pre-existent who is filled with the powers of the Holy Spirit which the Scripture enumerates by Isaiah, as if he were in lack of them?"

\section{Justin replies:}

"The Scripture says that these enumerated powers of the Spirit came on him not because he stood in need of them but because they would rest in him, that is, would find their completion in him, so that there would be no more prophets in your nation ... ; for after him no prophet has arisen among you. Now your prophets each received some one or two powers from God. Solomon possessed the spirit of wisdom, Daniel that of understanding and counsel, Moses that of might and piety, Elijah that of the fear (of God) and Isaiah that of knowledge $(\gamma \nu \bar{\omega} \sigma(s)$. And so with others, each possessed one power (of the Spirit). Accordingly it 'rested,' that is, ceased, when that One came after whom it was requisite that such gifts should cease from you, and having received their 'rest' in Him, should again become (separate) gifts which He imparts to those who believe on Him, according as he deems each man worthy."

Here is our complete definition of the doctrine of the 'pleroma' of the 'powers' or 'gifts of the Spirit' finding their 'rest' in the Son. The Jewish-Christian Gospel puts it in most succinct form: "The 'whole fountain' of the Spirit descended and 'rested' on Jesus at his baptism and said, 'My Son, I was waiting for thee in the prophets, but thou art my 'rest,' thou art my First-born."' And this is the same doctrine declared by Paul to the Colossians as 
" the revelation of the mystery hid from all ages and generations but now manifested unto the saints, to whom it was the good-pleasure of God to make known what is the riches of the glory of this mystery among the Gentiles, which is Christ in (or among) you, the hope of glory."

For, as he had said in the preceding context, "We have our redemption in the Son of His love" (=Eph. 16 , "the Beloved"), who is

" the First-born of all creation ... for all things have been created through Him and unto Him, and $\mathrm{He}$ is before all things and in Him all things have their consistency. . . . For it was the good-pleasure

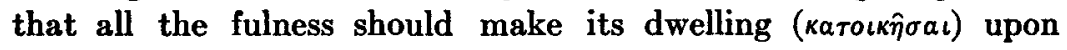
Him."

The phraseology ("the Beloved," "the First-born," "mystery hid from the ages," "before the creation," "the good-pleasure," "the fulness," "manifest among the Gentiles") shows that Justin and the Jewish-Christian Gospel and Paul are all dealing with stereotyped conceptions common to Judaism and Christianity. Moreover there is an unmistakable affinity with the baptismal vision of Mk. $110 \mathrm{f}$. and its Synoptic parallels. The root-idea of both is the doctrine of the 'tabernacling' of the Logos in the midst of the chosen (Ecclus. 24 8), which in Jn. 114,16 becomes a fulness $(\pi \lambda \dot{\eta} \rho \omega \mu a)$ of grace and truth, a 'fulness' from which we all receive. The Pauline doctrine then is not derived from the Synoptic story of the election of the Son. The roots of both are in lyric Wisdom. Lyric Wisdom sings of a First-born of the creation, "the instrument by which the world was created, and which was given to Israel," that "spirit of the Lord which hath filled the world and holdeth all things together"' (Sap. 1 7). Lyric Wisdom knows also' how "in every generation entering into holy souls it maketh men to be prophets and friends of God," but declares that its 'rest' in its 'fulness' is in Israel the Beloved Son, and Israel's representative the Messiah. 
The Pauline doctrine and the Synoptic are parallel developments from a common root. So also is the Logos doctrine of Jn. 1 14, 16-18, concerning the 'Only-begotten' Son endowed with the 'pleroma of grace and truth,' whose function is to 'declare the Father.' If the Pauline and Johannine conception of the election of the Son to be the Revealer of the Unknown Father can be said to have a Christian literary derivation, it will be an earlier form than the Synoptic enunciation of the good-pleasure. It will be the 'Hymn of Thanksgiving' of the Second Source, whose three strophes celebrate respectively: I, The Election of the Beloved in the divine Good-pleasure as custodian of the hidden Mystery; II, The Adoption to Sonship as Organ of Revelation; III, The Appeal to Men to accept the Easy Yoke. But the Pauline and Johannine developments are far too rich to be thus simply accounted for. They have behind them the copious elaboration of Isaian themes in Jewish and Alexandrian lyric Wisdom, whereof the Odes of Solomon form but the latest and most mystical development. In this literature it is that the transition is made by slow stages of advance from a nationalistic to an individualistic interpretation of the titles the 'Son,' the 'Beloved,' the 'First-born' and 'Only-begotten.'

The hymn of Mt. $1125-30=\mathrm{Lk} .1021 \mathrm{f}$. is a lyric of the divine Wisdom, like those of the Odes of Solomon, and the Jewish and Hellenistic odes on which these rest. The present setting of both is Christian, and the degree and proportion of Christian coloration will doubtless long remain a subject of dispute. The vital point is that we now have the key to their interpretation, and that key is the pre-Christian doctrine of Election-the Chosen People the divine Organ of Revelation. 